\title{
A story about stories: reflexivity in a conversation with a student of public policy
}

\author{
Greg Williams \\ College of Indigenous Futures, Arts \& Society, Charles Darwin University \\ greg.williams@cdu.edu.au
}

Keywords: Inhabiting stories; disconcertment; reflexivity; epistemic demeanour; epistemic accountability

\begin{abstract}
What happens when just an ordinary interaction with a student shifts your whole perspective on things? A routine conversation as course coordinator with one of our post-graduate public policy students took an interesting and insightful turn recently, and our interaction brought to light for me the importance of storytelling and the holding of disconcertment in the reflexive doing of difference, even in places where you would least expect it. Instead of holding a conversation where our words and stories acted upon each other from a distance, in this instance, I experienced the experience of inhabiting the conversation. I experienced knowing in action; a doing of knowing, where the participants, the stories and the tensions and vulnerabilities that attend our stories are inextricably linked together and embodied in the constituent act of being the conversation. Although I have engaged in complex and insightful discussion on many occasions, this conversation, seemingly unremarkable at its outset, caught me off guard. It drew me into a process entirely unexpected, constituted through the inhabiting of the experience and the reflexive opportunities it presented. This paper seeks to describe and provide some analysis of this 'experience of an experience' with a view to understanding something more of the processes of 'knowing in action' and its role in skilling us to work better with difference.
\end{abstract}

\section{Introduction}

Who would have thought that what was slated to be a fairly mundane and routine conversation with a student about her enrolment in a course of study could become an important moment of insight into how people enact 'knowing in action'? As it turns out, the encounter I describe in this paper was one of those moments when the experience caused my epistemic foundations to shift and provided the opportunity to begin to better understand our interactions with each other from a different perspective.

Public policy in northern Australia is complex and necessarily reflexive, and our teaching and study of it necessitates both a cultivation, and a demonstrated praxis, of reflexivity. As a postgraduate student in public policy at Charles Darwin University, Linda had found her study both engaging and challenging, but also frustrating because of the constraints of a semesterbased system. How can she study effectively when her commitments to work and family invariably overlap with the prescribed periods of study? She made an appointment to discuss the business of her study and nothing made me think this would be anything more than a 'mechanical' and 'perfunctory' meeting (Dewey, 1934, p. 43), but an increasing awareness of the reflexive nature of our teaching and learning demanded I pay attention to the epistemic 
work that was being carried out when we met and what unfolded was 'an interplay' within which 'a new experience develop(ed)' (Dewey, 1934, p. 44).

Working in an interesting corner of the academy where other ways of knowing, including those of Indigenous Australians, are valued and sometimes privileged, and where various modes of transdisciplinarity are emerging, this kind of epistemic disconcertment is not altogether uncommon. Where I work, different worlds are coming together in regular but unpredictable moments and can have the effect of sometimes knocking you off your 'feet' in a figurative and epistemic sense. This provides opportunity for experiencing things in novel ways that open up the prospect of being, knowing, and ultimately doing differently. It also requires a level of reflexivity that inhabits what Mouzelis (2008) describes as 'intra-habitus' experiences, those tensions 'that are constitutive of our routine human actions' (p1). Woolgar (1988, p. 92) calls us to be reflexive in our practice and to pay attention to the representations we find ourselves performing, so attending to the opportunities for reflexivity in this somewhat routine experience was an enlightening and insightful shift in the knowing, being and doing of everyday conversation. It enabled me to enact something of the epistemic accountability that Kenney (2015) claims is central to Helen Verran's work (2001, 2018 for example) which 'emphasizes the self in relation to a collective and draws attention to how value is calculated and enacted in everyday life' (Kenney, 2015, p. 750). It opened up the opportunity to inhabit experiences in ways that had been unfamiliar to me until that moment.

\section{An experience of an experience}

My father was an inveterate storyteller and I was raised on a diet of stories of adventure set in what was then the faraway north of Australia. It was a distant and exotic part of the world and the stories were always about larger-than-life people and events in places that were so different from the urban life into which I was born. The stories had a profound effect on me (and still do). Frank's (2010) account of the agency of narrative resonates for me very deeply in the way in which those stories from my youth still follow me around today, influence my actions and shape my interactions with my own family and friends. There is a sense in which those stories of the north constrain and open up opportunity for me to construct particular identities (Kerby, 1991) in the various communities within which I engage now that I too live in that same geographical location. And therein lies the issue. Stories are integral; they affect and shape you, but until this experiential moment with this particular student, I had always inferred that they worked independently from me and at a distance.

My father's stories were always stories that happened back then, in somewhat exotic times and places. They reach forward in time to affect the person I am now and what I do, but I never recognised them, or have taken them seriously, as acting from anywhere else but the past. Similarly, until now l've understood even contemporary stories to act at a distance. I have been treating them like objects that are bounded either temporally or geographically and worked on me from afar. They are from this point of view, as Stoller (2018) would suggest, 'ontologically discreet' (p. 48). I expected my conversation with Linda to be the something of the same - somewhat mechanical and perfunctory. I anticipated it to be an uneventful interaction. I understood the social constructed-ness of her position and the agency of various actors in her stories, but my expectation was that the conversation's impact upon me and my working life would be inferred and their effect likely to be minimal. This time, the stories would come from the other side of a table, but they would still be working on me from a distance. I certainly 
wasn't prepared for an experience where the conversation was literally performed as a kind of linguistic and metaphorical 'dance' that we inhabited in the space between us.

As with many post-graduate students, Linda's life is a busy one and the complexity of managing full time work, full time family and part time study was likely a challenge. She had come to see me to discuss her options and explore how flexible study could be. Regular study timelines weren't going to work for her, and she needed to see if there were other ways to progress through the course on her own timeline. She was a little flustered perhaps; perhaps annoyed that things weren't working for her or perhaps she was disappointed in not being able to meet her own expectations of herself or the university. Her manner signalled to me that I needed to talk more and establish my credentials as someone she could trust. She had a stake in the conversation - she needed some flexibility. I had a stake in the conversation - I needed to show her that I was competent and trustworthy because she was offering to place decisions about her future studies in my hands, and reveal her vulnerability in doing so. In my position, I needed to treat her trust with the respect that the situation demanded, and I needed to gauge the level of commitment to study she actually possessed. This was a somewhat familiar engagement, between two somewhat familiar characters found in any tertiary institution; a confident, though probably stressed student and a concerned but cautious and canny academic. It was a common situation which nevertheless still needed careful handling.

So, we talked. Linda told me something of her situation and relevant parts of her life story. I listened and told her stories about my situation and some of my life story too - including stories drawn from, and infused with, the adventures relayed to me by my father. Many encounters with students are perfunctory exchanges of information and we each wait in turn to speak and to impart the information we think the other person wants or needs to hear. The stories would normally be seen, by me at least, as objects of interest and a form of a currency exchanged between participants. But this time it was different. In retrospect, it seemed as if the conversation were being conducted at slow speed, slow enough for me to reflect on the experience as we both spoke. People moved past my open office door in what seemed to be slow motion, and the words (both hers and mine) seemed to echo around in my brain for a second or two giving me time to observe them before they settled into familiar tracks. The experience was beginning to look and feel like something akin to what Verran (2014) describes as the ontic - what Dewey (1905) would have described as an 'experience of an experience'. It is an experience (of an experience) that brings with it a level of intensity and a heightened sense of awareness that draws you in and stirs your curiosity. The experience craved my immediate attention, demanded an immediate reflection and response, and it certainly drew me in. It was a juxtaposition of being very much in the experience and yet feeling distinctly outside of it; an integral and immediate presence and a sense of objective otherness and dissociation at the same time. It was all happening in what, on one hand seemed like treacleish, almost inert moments, so I was able to reflect and respond as the event unfolded around me. Yet, at the same time, the flow of time seemed normal and I was encountering myself inhabiting the space and conducting the careful work of a course coordinator in the moment.

As I reflected on the encounter, I began to render the experience in a frame that connected what was, in this moment, an intuitive, sensed experience with what had previously been a distant and inferred theoretical concept of storytelling - a concept that, in retrospect, had never really quite landed anywhere in a way that would allow me to inhabit it as a knower - it always had kept its distance. This rendering was something like an 'imaginary', which Verran describes "as not a thing of the mind... [but] constituent of the very situation of doing or action" (Verran, 
2001 , p. 37). It was very much an embodied act of doing conversation and being able in the same moment, to participate fully and to observe and reflect from some imaginary vantage point. Both acts were inseparably tied together - all constituting the event. The experience was momentary, but unexpectedly it has proven to be a far more valuable encounter for me than I could have guessed at the outset of the conversation. Two things emerged from the meeting with Linda that I have constructed into a working imaginary that Verran (2018) would perhaps describe as epistemic demeanour.

When we met, Linda and I made our acquaintances and cast about for connections - in Darwin, the degree of separation is often very small. This led to telling histories, unveiling rationales and an initial and somewhat fragmentary building of a shared experience of our location, people and the community. As the encounter ensued, it became clear to me that this wasn't just an ordinary, information imparting consultation, we were telling each other stories; stories about travel and reasons for travel; about very specific, particular and local experiences - gauging our reactions to them and assessing our familiarity with them. We weren't telling it 'straight', we weren't addressing things we wanted to say directly, but we were using important narratives from our own experiences to create a shared space of operation within which we could trust that our 'business' could be conducted equitably and constructively. We each consciously, intentionally and carefully 'danced' around each other with our 'stories'.

At one point, Linda said that 'living in Darwin had spoiled her for living anywhere else in the country'. She had come north to deliberately challenge her sensibilities and make herself feel uncomfortable and now felt 'comfortable in her discomfort'. She sensed that many of the issues that challenge us as a nation and particularly in relation to Indigenous Australians' sovereignty and worldviews were visible, stark and raw in the north, and her aim was a deliberate and calculated experience of tension - visceral epistemological tension. This tension was also present in our interaction and was held in the place between us by our stories.

So, what had happened here? What was so important in this encounter that I should consider its rendering so unfamiliar? This interaction, on face value, had the initial hallmarks of a routine encounter, but I was utterly and absolutely moved and transformed by it. Here was an interaction where all the usual cues that would tell me I would be engaging with a person who had different ways of knowing were absent. And yet, here I was immersed in the experience of an experience where we were so obviously (to me, in my creation of the imaginary) both telling stories and holding the tension of the encounter in the space between us. Whilst there was nothing overt to signal it, here we were (or at least, here I was) very obviously inhabiting the epistemic work of doing difference.

Now, not only do I see stories everywhere and everywhen, I see the possibilities of how I literally inhabit them. Even the most perfunctory information transactions are potential inhabitations of a story. Previously, the narrative nature of these transactions could be theoretically rendered something which was separate and objective, but here I had the experience of an experience where theory and conceptual frame merged with a real encounter in a way that brought the process into stark relief and sudden realisation, perhaps for the first time. Previously, stories enacted in conversations had been elided and treated as commonplace transmission of objective fact. Somehow, in this experience, I found my conscious self, paying attention to the doing of difference, the 'dancing of stories' and the holding of each other's vulnerability in a place where I hadn't expected to be confronted by such a thing, here in my office on a very ordinary and commonplace day. 


\section{Epistemic demeanour}

Verran (2018) uses the term 'epistemic demeanour' to characterise this paying of attention to stories and the cultivation of epistemic accountability (Kenney, 2015). Our stories, however easily they can be overlooked as fact or information, are visible and/or audible representations of our worldviews. What stories we tell and how we tell them demonstrates what we value most and gives clues as to how we would defend them when and if it came to it. Kerby (1991) and Frank (2010) both make claim for the work done through and by stories in meaning making. We shape the world by our stories and in turn, in their telling they shape us. They make us vulnerable, by compelling us to act in certain ways, they can in their enactment lay bare some of our innermost and deepest held beliefs and values. To tell stories is to place us in a position of tension with our listeners, because we make ourselves visible and open to critique and potentially derision and ridicule. Each of the narratives that Frank (2010) uses to demonstrate the agency of stories, ooze vulnerability and I discovered in this encounter that this is made all the more visceral in the inhabiting of them.

In many ways, and certainly in my imaginary, Linda was enacting her 'holding onto disconcertment' by engaging in conversation with me. She had travelled north many years ago to deliberately seek out epistemic (and perhaps physical) discomfort and had held onto that. It had made her sick (she said), it had caused embarrassment (her stories exemplified), and (in her words) it had produced both failure and success. Disconcertment was, without doubt to anyone who heard her tell it, writ large in her experience, and here she was telling me these same stories and allowing me to inhabit them and, in a sense, (re)experience them with her.

Our conversation drew both Linda and myself into a vulnerable space. Her stories danced around sick parents, competing work pressures and expectations of family members. The stories and their literal meaning making was full of vulnerabilities - each story hinting at challenging conversations that had occurred and battles with various agencies. But, and perhaps more importantly, every part of what we spoke opened each of us up to disconcertment. The discussion about actions of government, the airing of views about certain policies and legislation placed us both in a complex web of narratives that demonstrated who we were and what we believed, as well as any manifesto could. I knew where she stood on the things we considered important and vice versa. The conversation had done its job, but only because of both of our abilities at the time to exercise an epistemic demeanour that pays attention to both the narrative and each other's tension and discomfort. What came from it? Linda and I, through our careful recognition of tension and disconcertment and the respectful reception and holding of each other's stories (as rendered in my imaginary), created a safe and generative interactive space (however temporary) that allowed us to share something of ourselves and conduct the necessary business that was required.

\section{Conclusion}

What was initially slated as an ordinary and likely unremarkable meeting, has now constituted a fundamental shift in the way in which I choose to see my interactions with people. As a scientist by trade, I've been trained to treat information in an objective and transmissible way - in a scientific context, knowledge is treated as a commodity. As a listener and now teller of my own stories, even they were things - 'objects' that worked their agency from a 
distance. Working in transdisciplinary arenas with different doers of knowing however, l've learned more about how disconcertment and narrative play a central role in knowledge making as we inhabit the experiences of our interactions with each other and view those interactions not as transactional encounters, but as a shared doing of knowledge. These things are crucial constituents of, and markers in, our encounters with each other and a recognition as such is a step in the cultivation of an epistemic demeanour that helps us pay attention to the ways we inhabit the stories we tell each other and work of doing difference.

\section{References}

Dewey, J. (1905). The Postulate of Immediate Empiricism. The Journal of Philosophy, Psychology and Scientific Methods, 2(15), 393-399.

Dewey, J. (1934). Art as Experience, New York: Capricorn Books.

Frank, A.W. (2010). Letting Stories Breathe: A Socio-Narratology. Chicago: University of Chicago Press.

Kenney, M. (2015). Counting, accounting, and accountability: Helen Verran's relational empiricism. Social Studies of Science, 45(5), 749-771.

Kerby, A. (1991). Narrative and the self (Studies in Continental Thought). Bloomington: Indiana University Press.

Mouzelis, N. (2008). Habitus and Reflexivity: Restructuring Bourdieu's Theory of Practice. Sociological Research Online, 12(6), 1-6.

Stoller, A. (2018) Dewey's Creative Ontology. Journal of Thought 52(3/4): $47-64$.

Verran, H. (2018). The Politics of Working Cosmologies Together While Keeping Them Separate. In M. de la Cadena \& M. Blaser (Eds.), A World of Many Worlds (pp. 112-130). Durham, NC: Duke University Press.

Verran, H. (2014). Working with those who think otherwise. Common Knowledge 20(3): 527 - 539.

Verran, H. (2001). Science and an African Logic. Chicago: University of Chicago Press.

Woolgar, S. (1988). Science, the very idea (Key ideas). Chichester, Sussex: London; New York: Ellis Horwood; Tavistock Publications 